\title{
ESTRUCTURA DEL INGRESO Y CONSUMO DE HOGARES RURALES EN DIFERENTES REGIONES AGRO-ECONÓMICAS DE PUEBLA, MÉXICO
}

\section{INCOME AND CONSUMPTION STRUCTURE OF RURAL HOUSEHOLDS IN DIFFERENT AGROECONOMIC REGIONS OF PUEBLA, MÉXICO}

\author{
Venkatesh Gurusamy ${ }^{1}$, Leobardo Jimenez-Sanchez ${ }^{2}$, José L. Jaramillo-Villanueva ${ }^{1 *}$, Daniel C. Martínez-Carrera ${ }^{1}$, \\ Miguel Sánchez-Hernández ${ }^{1}$, María E. Méndez-Cadena ${ }^{1}$
}

\begin{abstract}
${ }^{1}$ Campus Puebla. Colegio de Postgraduados. Colonia Momoxpan, San Pedro Cholula, Puebla. (jaramillo@colpos.mx). ${ }^{2}$ Desarrollo Rural. Campus Montecillo. Colegio de Postgraduados. Montecillo, Estado de México. 56230.
\end{abstract}

RESUMEN

La importancia del estudio del bienestar social de los hogares rurales a nivel municipal radica en que los resultados pueden ser usados para proponer estrategias de intervención específicas, atendiendo características productivas, socio-económicas y ambientales. Este estudio tuvo como objetivo calcular y analizar indicadores de bienestar socio-económico; pobreza y desigualdad del ingreso, y su relación con características sociodemográficas y productivas de los hogares rurales. Los datos se obtuvieron usando un cuestionario estructurado aplicado a una muestra de 141 hogares y a través de entrevistas en profundidad a informantes clave. Se utilizó un muestreo estadístico aleatorio simple. El tamańo de muestra se determinó con una confiabilidad de $95 \%$ y una precisión de $5 \%$. El estudio se realizó en tres municipios del estado de Puebla: San Salvador el Verde, Tlapanalá, y Coatzingo. Los resultados indican que existen diferencias significativas en el ingreso y consumo de los hogares, explicado por la diversificación del ingreso, el acceso a activos productivos y por la calidad del temporal. La desigualdad, estimada por el índice de Gini, es alta; 0.502, 0.439, y 0.416 para San Salvador el Verde, Tlapanalá y Coatzingo, respectivamente. Los factores explicativos de la desigualdad son el valor de los activos de herencia, el índice de capital humano, y el valor de las transferencias a nivel municipal. El índice de pobreza para los tres municipios es mayor que el reportado por CONEVAL en 2014.

Palabras clave: bienestar social, desigualdad del ingreso, hogar rural.

* Autor responsable * Author for correspondence.

Recibido: febrero, 2016. Aprobado: junio, 2017.

Publicado como ARTÍCULO en ASyD 15: 215-233. 2018.

\section{Abstract}

The importance of the study of social welfare of rural households at the municipal level lies in that the results can be used to propose specific intervention strategies, addressing productive, socioeconomic and environmental characteristics. This study had the objective of calculating and analyzing indicators or socioeconomic welfare, poverty and income inequality, and their relation with sociodemographic and productive characteristics of rural households. The data were obtained using a structured questionnaire applied to a sample of 141 households and through in-depth interviews with key informants. Simple random statistical sampling was used. The size of the sample was determined with a reliability of 95 $\%$ and an accuracy of $5 \%$. The study was performed in three municipalities of the state of Puebla: San Salvador el Verde, Tlapanalá and Coatzingo. The results indicate that there are significant differences in the income and consumption of the households, explained by the diversification of income, access to productive assets, and quality of seasonal rains. The inequality, estimated by the Gini index, is high: 0.502 , 0.439 and 0.416 para San Salvador el Verde, Tlapanalá and Coatzingo, respectively. The explicative factors of inequality are the value of the inheritance assets, the human capital index, and the value of transferences at the municipal level. The poverty index for the three municipalities is higher than the one reported by CONEVAL in 2014.

Key words: social welfare, income inequality, rural household.

\section{INTRODUCTION}

The study of social welfare of the population has a long history in México and in the world, because it provides information for decision making in fiscal policy and about the type 


\section{INTRODUCCIÓN}

$\mathrm{E}$ l estudio del bienestar social de la población tiene una larga historia en México y en el mundo, debido a que aporta información para tomar decisiones de política fiscal y sobre el tipo de programas necesarios para mejorar el ingreso y el consumo de los hogares. Recientemente, este tema ha cobrado mucha importancia debido a que la situación de pobreza de la población no ha mejorado en los últimos 30 ańos e incluso ha empeorado en algunos periodos. La proporción de la población en situación de pobreza alimentaria y pobreza de patrimonio en 1992 era de 21.4 y $53.1 \%$, y en 2014 fueron de 20.6 y $53.2 \%$, respectivamente (CONEVAL, 2015).

El bienestar social es un concepto de naturaleza compleja, no medible directamente, y puede ser definido de distintas maneras de acuerdo con la teoría del bienestar que se tenga en cuenta (Di Pasquale, 2008). En la literatura sobre el desarrollo económico y social existe una larga tradición de medición; sin embargo, fueron los economistas del bienestar quienes aportaron soporte teórico al concepto de bienestar social (Debreu, 1959; Sen, 1970; Arrow, 1974).

En la literatura se identifican diferentes enfoques para abordar el concepto de bienestar social. Sen (1999) realiza una crítica de dos enfoques muy utilizados. La igualdad utilitaria, con fundamentos en la economía clásica del bienestar; y la justicia distributiva, sustentada por Rawls (1971). La igualdad utilitaria es aquella que puede derivarse del concepto de utilidad marginal, según la cual cada persona obtiene mayor utilidad, en la medida que consume una mayor cantidad de cierto bien, y su utilidad aumenta a una tasa decreciente, sin considerar aspectos de distribución. La justicia distributiva se caracteriza por una igualdad en la dotación de "bienes sociales primarios"; estas son "cosas que todo hombre racional se presume necesita», incluidos "los derechos, libertades y oportunidades, el ingreso y la riqueza, y las bases sociales del respeto de sí mismo". Las libertades básicas tienen prioridad sobre los otros bienes sociales primarios.

Sen (1992) argumenta que los enfoques anteriores no dan cuenta adecuadamente del concepto de bienestar social porque ignoran que un componente fundamental del bienestar son las "capacidades" y "habilitaciones" de las personas. Las primeras son of programs necessary to improve the income and consumption of households. Recently, this issue has taken on much importance because the situation of poverty of the population has not improved in the last 30 years and has even worsened in some periods. The proportion of the population in situation of food poverty and asset poverty in 1992 was 21.4 and $53.1 \%$, and in 2014 it was 20.6 and $53.2 \%$, respectively (CONEVAL, 2015).

Social welfare is a concept of complex nature, not directly measurable, and can be defined differently according to the theory of welfare that is being considered (Di Pasquale, 2008). In the literature about economic and social development there is a long tradition of measurement; however, it was the welfare economists who contributed theoretical support to the concept of social welfare (Debreu, 1959; Sen, 1970; Arrow, 1974).

In the literature, different approaches were identified to address the concept of social welfare. Sen (1999) carries out a critique of two approaches that are very often used. Utilitarian equality based on classical welfare economy; and distributive justice, sustained by Rawls (1971). Utilitarian equality is the one that can be derived from the concept of marginal utility, according to which each person obtains higher utility to the extent that he/she consumes a higher amount of certain good, and his/her utility increases at a decreasing rate, without taking into account aspects of distribution. Distributive justice is characterized by equality in the endowment of "primary social goods"; these are "things that are presumed to be needed by every rational human being", including "the rights, freedoms and opportunities, the income and wealth, and the social bases for self-respect". The basic freedoms have priority over the other primary social goods.

Sen (1992) argues that these approaches do not adequately account for the concept of social welfare because they ignore that a fundamental component of welfare are the "capacities" and "capabilities" of people. The first are defined as the opportunities for choice regarding the way that a person wants to live. Thus, life quality depends on what the subject is capable of obtaining, the ways in which he/she is capable of living, and not just on his/her economic resources to satisfy basic needs. The "capabilities" are resources regarding about which there is a real possibility of use and a person is enabled, regarding 
definidas como las oportunidades de elección sobre la forma en que desea vivir. Así, la calidad de vida depende de lo que el sujeto sea capaz de conseguir, de las maneras en que sea capaz de vivir, y no solo de sus recursos económicos para satisfacer necesidades básicas. Las "habilitaciones" son recursos respecto de los que existe una posibilidad real de uso y una persona está habilitada respecto de ciertos recursos cuando puede ponerlos a su disposición para utilizarlos o consumirlos. A partir de este enfoque, el desarrollo social se entiende como un proceso de expansión de las libertades que las personas valoran y tienen razones para valorar (Cejudo, 2007).

\section{La desigualdad social}

La desigualdad se refiere a una distribución no equitativa de oportunidades o de la riqueza generada en una sociedad. La desigualdad social es la distribución asimétrica de bienes y servicios como salud, educación, e ingreso entre los hogares, clases sociales, género y razas de una sociedad (Conapo, 2005).

El concepto de "Desigualdad es más amplio que el de pobreza, en tanto es definido sobre el total de una distribución dada, y no solo sobre una parte de la distribución de ingresos de los individuos (u hogares) que está definida por debajo de cierta línea de pobreza" (Rodríguez, 2008). Este es independiente de la media de la distribución y en su lugar exclusivamente se aborda el segundo momento: la dispersión de la distribución (Litchfield, 1999).

La desigualdad social se manifiesta en problemas como el deterioro del ingreso, la depreciación del trabajo y la baja cobertura de los servicios sociales básicos. La desigualdad en la distribución del ingreso, específicamente, repercute en el empleo, la educación, la salud, la vivienda, y el espacio público y residencial, y segmenta la vida social.

El estudio del Bienestar requiere atender a múltiples factores históricos, culturales y políticos, además de los económicos. Entre éstos últimos se toma en cuenta la distribución del ingreso entre todos los componentes del grupo social (la familia, u hogar). Sin embargo, estos tres conceptos pertenecen a una misma familia y en general los indicadores utilizados para medirlos son compuestos (Haughton y Khandker, 2009).

En la literatura sobre la desigualdad social los indicadores de desigualdad pueden ser medidas positivas, las certain resources, to place them at his/her disposition to be used or consumed. From this approach, social development is understood as an expansion process of the freedoms that people value and have reasons to value (Cejudo, 2007).

\section{Social inequality}

Inequality refers to a non-equitable distribution of opportunities or wealth generated in a society. Social inequality is the asymmetrical distribution of goods and services such as health, education and income between households, social classes, gender, and races in a society (Conapo, 2005).

The concept of "Inequality is broader than poverty, insofar as it is defined based on the total of a given distribution, and not only on a part of the income distribution of individuals (or households), which is defined to be under a certain poverty line" (Rodríguez, 2008). This is independent of the distribution mean and, in its place, the second moment is addressed exclusively: distribution dispersion (Litchfield, 1999).

Social inequality is manifested in problems such as the deterioration of income, the depreciation of work, and the low coverage of basic social services. The inequality in income distribution, specifically, has an effect on employment, education, health, housing, and public and residential space, and it segments social life.

The study of Welfare requires addressing multiple historical, cultural and political factors, in addition to the economic. Among the latter, income distribution between all components of the social group (family or household) is taken into account. However, these three concepts belong to the same family and in general the indicators used to measure them are compound (Haughton and Khandker, 2009).

In the literature about social inequality the indicators of inequality can be positive measures, which do not refer explicitly to any concept of social welfare and the regulations, based on a function of welfare. To the first group belong the statistical indexes traditionally used to analyze the dispersion of a distribution of frequencies such as variance, standard deviation, coefficient of variation, and analysis of quantiles. Meanwhile, to the second group belong those that are based on a function of social welfare such as the Gini index, the Lorenz curve, and 
cuales no hacen referencia explícita a ningún concepto de bienestar social y las normativas, basadas en una función de bienestar. Al primer grupo pertenecen los índices estadísticos que tradicionalmente se utilizan para analizar la dispersión de una distribución de frecuencias como la varianza, la desviación estándar, el coeficiente de variación, y el análisis de los cuantiles. En tanto, al segundo grupo pertenecen aquellos que están basados en una función de bienestar social como el índice de Gini, la Curva de Lorenz, y el índice de Theil (Haughton y Khandker, 2009). En este estudio estimamos la desigualdad con el índice de Gini y con el de Theil.

\section{Concepto de ingreso y consumo}

En México, a partir del mandato de la Ley de Desarrollo Rural Sustentable (LDRS), para medir el bienestar social de la población se emplea un patrón de consumo que refleja un mínimo de bienestar y cuyo precio de mercado constituye la línea de pobreza (CONEVAL, 2015). Así, los hogares cuyo ingreso está por debajo de esta se consideran pobres por ingreso. La incidencia de la pobreza por ingresos es un indicador ampliamente utilizado a escala mundial que refleja el porcentaje de la población en un cierto ámbito que no cuenta con los recursos monetarios suficientes para adquirir los bienes y servicios considerados como necesarios en su entorno social.

Con el propósito de hacer comparables los resultados de esta investigación se utilizó el concepto de ingreso que propone INEGI (2015) y que es el mismo que utiliza CONEVAL en las mediciones de bienestar y pobreza en México. El concepto de ingreso es el que se forma por las entradas monetarias y no monetarias que satisfacen tres criterios: regularidad, disponibilidad y patrimonio. De acuerdo con INEGI, el ingreso corriente se compone de las siguientes cinco categorías: ingreso del trabajo; renta de la propiedad; transferencias; estimación del alquiler de la vivienda; y otros ingresos corrientes (INEGI, 2010). Dadas las características del este estudio y por cuestiones de costos no es posible imputar un valor para el alquiler de la vivienda, ni de renta de la propiedad, por lo que, por simplicidad, no se tomarán en cuenta para las estimaciones de ingreso. the Theil index (Haughton and Khandker, 2009). In this study we estimate the inequality with the Gini and Theil indexes.

\section{Concept of income and consumption}

In México, since the mandate of the Sustainable Rural Development Law (Ley de Desarrollo Rural Sustentable, LDRS), to measure the social welfare of the population, a pattern of consumption that reflects a minimum of welfare is used and whose market price constitutes the poverty line (CONEVAL, 2015). Thus, the households whose income is below this are considered to be income poor. The incidence of income poverty is an indicator that is broadly used worldwide which reflects the percentage of the population in a certain scope that does not have the sufficient monetary resources to acquire the goods and services considered as necessary in their social environment.

With the purpose of making the results from this research comparable, the concept of income that INEGI (2015) proposes was used, and which is the same that CONEVAL uses in the measurements of welfare and poverty in México. The concept of income is formed by the monetary and non-monetary entries that satisfy three criteria: regularity, availability and patrimony. According to INEGI, the current income is made up of the following five categories: income from work; property rental; transferences; estimation of housing rent; and other current incomes (INEGI, 2010). Given the characteristics of this study and because of cost issues, it is not possible to attribute a value for housing rent, or property rental, which is why for simplicity they will not be taken into account for the income estimations.

\section{The welfare situation of rural households in México and Puebla}

The state of Puebla is the fifth most populated state in México, with 5.78 million inhabitants and the ninth in contribution to the Gross Domestic Product (INEGI, 2010). However, it is also one of the entities with greatest social backwardness and income inequality; it occupies the fourth place, after Guerrero, Oaxaca and Chiapas. By 2014, the population in situation of poverty and extreme poverty was $64.5 \%$ and $16.2 \%$, respectively. The 


\section{La situación de bienestar de los hogares rurales en México y Puebla}

El estado de Puebla es la quinta entidad más poblada de México, con 5.78 millones de habitantes y la novena en contribución al Producto Interno Bruto (INEGI, 2010). Sin embargo, también es una de las entidades con mayores rezagos sociales y desigualdad del ingreso; ocupa el cuarto lugar, después de Guerrero, Oaxaca y Chiapas. Para 2014, la población en situación de pobreza y pobreza extrema fue de $64.5 \%$ y $16.2 \%$, respectivamente. La población sin acceso a bienestar fue de $69.7 \%$ (CONEVAL, 2015).

Respecto al ingreso monetario, la forma más utilizada para conocer su distribución es usar alguna medida de desigualdad, como el coeficiente de Gini o el de Theil. Para el estado de Puebla, el índice de Gini pasó de 0.48 en 2010 a 0.57 en 2014 , situación que deberá atenderse pues este índice disminuyó a nivel nacional; pasó de 0.50 a 0.48 en el mismo periodo, otro aspecto que da cuenta de la situación de rezago social del estado es la inseguridad alimentaria, que fue de $26.2 \%$ en 2014, y se ha mantenido casi sin cambio en los últimos años, pasando de $26.4 \%$ en 2010 a 25.2\% en 2015 (CONEVAL, 2014; 2015).

La situación de pobreza y desigualdad podría explicarse por una serie de carencias que limitan las oportunidades de la población, tales como el rezago educativo, la seguridad social, y los servicios de salud, que fueron de $25.3 \%, 72.3 \%$ y $40.4 \%$, respectivamente, en 2010. Para 2015 las dos primeros carencias no mejoraron de forma importante, con valores de $22.9 \%$ y $71.3 \%$, respectivamente, mientras que la carencia de acceso a servicios de salud fue de $18.9 \%$ en este último año.

En Puebla, a nivel municipal, la situación del ingreso y su distribución presentan importantes contrastes, pues mientras en 2014 Chichiquila presentó $96.3 \%$ de sus habitantes en situación de pobreza de patrimonio, Santa María Tlaltempan tuvo $3 \%$ en esta condición, lo que en términos relativos es bueno y lo ubica como uno de los municipios a nivel nacional con menor incidencia.

En cuanto a la zona de estudio, el municipio de Tlapanalá tiene una población de 7063 habitantes, con un Índice de Desarrollo Humano (IDH) de 0.805; el índice de Gini es de 0.38 y $80.9 \%$ de la población con pobreza de patrimonio. San Salvador el Verde, con una población de 24 812, tiene un IDH population without access to welfare was $69.7 \%$ (CONEVAL, 2015).

Regarding the monetary income, the most frequently way of knowing its distribution is using an inequality measure, such as the Gini or Theil coefficients. For the state of Puebla, the Gini index went from 0.48 in 2010 to 0.57 in 2014 , situation that should be addressed for this index decreased at the national level; it went from 0.50 to 0.48 in the same period; another aspect that accounts for the situation of social backwardness in the state is food insecurity, which was $26.2 \%$ in 2014 , and has remained almost without change in recent years, moving from $26.4 \%$ in 2010 to $25.2 \%$ in 2015 (CONEVAL, 2014; 2015).

The situation of poverty and inequality could be explained by a series of shortages that limit the opportunities of the population, such as lags in education, social security, and health services, which were $25.3 \%, 72.3 \%$ and $40.4 \%$, respectively, in 2010. By 2015, the two first shortages did not improve in a relevant manner, with values of $22.9 \%$ and $71.3 \%$, respectively, while the lack of access to health services was $18.9 \%$ in this last year.

In Puebla, at the municipal level, the situation of income and its distribution presents important contrasts, for while in 2014 Chichiquila presented $96.3 \%$ of its inhabitants in situation of asset poverty, Santa María Tlaltempan had $3 \%$ in this condition, which in relative terms is good and places it as one of the municipalities with lowest incidence at the national level.

In terms of the study zone, the municipality of Tlapanalá has a population of 7063 inhabitants, with a Human Development Index (HDI) of 0.805; the Gini index is 0.38 and $80.9 \%$ of the population is in asset poverty. San Salvador el Verde, with a population of 24812 , has HDI of 0.815 ; Gini index, of $0.426 ; 69.5 \%$ of the population in asset poverty; and $13.5 \%$ in extreme poverty. Finally, Coatzingo had 2,714 inhabitants; HDI, of 0.7502 ; Gini index, of 0.4313; $76.6 \%$ of the population in asset poverty, and $30.8 \%$ in extreme poverty (Table 1 ).

The municipalities under study also present different productive and natural conditions. San Salvador el Verde obtains most of its agricultural and livestock income from the production of grains and porcine livestock, Tlapanalá from vegetables and 
Cuadro 1. Características sociales de los municipios en estudio. Table 1. Social characteristics of the municipality of study.

\begin{tabular}{lcccc}
\hline & Tlapanalá & San Salvador el Verde & Coatzingo & Estado de Puebla \\
\hline Población & 7063 & 24812 & 2714 & 5794763 \\
IDH & 0.8048 & 0.8147 & 0.7502 & 0.693 \\
Índice de Gini & 0.3786 & 0.4267 & 0.4313 & 0.452 \\
Pobreza (\%) & 80.9 & 69.5 & 76.6 & 61.2 \\
Pobreza extrema (\%) & 24.9 & 13.2 & 30.8 & 16.7 \\
Pobreza moderada (\%) & 56.0 & 56.3 & 45.7 & 44.5 \\
\hline
\end{tabular}

Fuente: INEGI. 2010; CONEVAL 2015. IDH: Índice de Desarrollo Humano. * Source: INEGI. 2010; CONEVAL 2015. IDH Human Development Index (HDI).

de 0.815; el índice de Gini, de 0.426; 69.5\% de la población en pobreza de patrimonio; y $13.5 \%$ en pobreza extrema. Finalmente, Coatzingo tenía 2,714 habitantes; IDH, de 0.7502; el de Gini, de 0.4313; $76.6 \%$ de la población en pobreza de patrimonio; y $30.8 \%$ en pobreza extrema (Cuadro 1).

Los municipios bajo estudio también presentan condiciones productivas y naturales diferentes. San Salvador el Verde obtiene la mayor parte de ingreso agropecuario de la producción de granos y ganado porcino, Tlapanalá de hortalizas y ganado bovino, y Coatzingo de hortalizas, frutales y ganado bovino (Cuadro 2).

De acuerdo a lo anterior, el campo tiene un papel relevante en la reproducción de los hogares, debido a bovine livestock, and Coatzingo from vegetables and bovine livestock (Table 2).

According to this, the countryside has a relevant role in the reproduction of households, because the agricultural and livestock income is an important source of food security and monetary income, much more so for San Salvador el Verde and Tlapanalá and, to a lesser degree, for Coatzingo and Tlapanala.

The hypothesis addressed in this study is that the social welfare of rural households, calculated based on the income and the consumption, is explained by sociodemographic, productive characteristics and by the environmental conditions under which they live. Thus, the objective is to calculate and analyze the behavior of indicators of socioeconomic

Cuadro 2. Valor de la producción agropecuaria de los municipios en estudio, 2014.

Table 2. Value of agricultural and livestock production in the municipalities of study, 2014.

\begin{tabular}{|c|c|c|c|c|c|c|}
\hline \multirow{2}{*}{ Cultivos } & \multicolumn{2}{|c|}{ San Salvador el Verde } & \multicolumn{2}{|c|}{ Tlapanalá } & \multicolumn{2}{|c|}{ Coatzingo } \\
\hline & $\begin{array}{c}\text { Valor } \\
\text { (Miles de pesos) }\end{array}$ & $\%$ & $\begin{array}{c}\text { Valor } \\
\text { (Miles de pesos) } \\
\end{array}$ & $\%$ & $\begin{array}{c}\text { Valor } \\
\text { (Miles de pesos) }\end{array}$ & $\%$ \\
\hline Hortalizas & 12509 & 11.9 & 84485 & 58.3 & 37314 & 54.0 \\
\hline Granos & 65371 & 62.1 & 32608 & 22.5 & 5445 & 7.9 \\
\hline Frutales & 6145 & 5.8 & 11705 & 8.1 & 24000 & 34.7 \\
\hline Flores & 21280 & 20.2 & - & & - & - \\
\hline Otros & - & - & 16160 & 11.1 & 2371 & 3.4 \\
\hline Total & 105305 & 100.0 & 144957 & 100.0 & 69131 & 100.0 \\
\hline \multicolumn{7}{|l|}{ Ganadería } \\
\hline Bovinos & 2581 & 15.0 & 1347 & 34.0 & 7313 & 72.1 \\
\hline Porcinos & 11254 & 65.6 & 851 & 21.5 & 2403 & 23.7 \\
\hline Ovinos & 929 & 5.4 & 925 & 23.4 & 76 & 0.8 \\
\hline Caprinos & 254 & 1.5 & 686 & 17.3 & 196 & 1.9 \\
\hline Aves & 1750 & 10.2 & 87 & 2.2 & 61 & 0.6 \\
\hline Guajolote & 394 & 2.3 & 64 & 1.6 & 91 & 0.9 \\
\hline Total & 17162 & 100.0 & 3960 & 100.0 & 10140 & 100.0 \\
\hline
\end{tabular}

Fuente: elaboración propia con datos de SIAP, 2015. Source: authors’ elaboration with data from SIAP, 2015. 
que el ingreso agropecuario es una fuente importante de seguridad alimentaria e ingreso monetario, mucho más para San Salvador el Verde y Tlapanala y, en menor medida, para Coatzingo y Tlapanala.

La hipótesis que aborda el presente estudio es que el bienestar social de los hogares rurales, calculado con base en el ingreso y el consumo, es explicado por características sociodemográficas, productivas y por las condiciones ambientales en que viven. Así, el objetivo es calcular y analizar el comportamiento de indicadores de bienestar socio-económico, su distribución, y su relación con las características sociodemográficas y productivas de los hogares rurales.

\section{Metodología}

\section{Localización del área de estudio}

El municipio de San Salvador el Verde se localiza en la parte centro oeste, del estado de Puebla. Sus coordenadas geográficas son los paralelos $19^{\circ} 12^{\prime} 18^{\prime \prime}$ y $19^{\circ} 21^{\prime} 54^{\prime \prime} \mathrm{N}$ y los meridianos $98^{\circ} 26^{\prime} 54^{\prime \prime}$ y $98^{\circ} 93^{\prime}$ $18^{\prime \prime} \mathrm{O}$. En el municipio se presenta la transición de los climas templados del Valle de Puebla y los semifríos de las partes bajas de la Sierra Nevada. La temperatura media anual es entre 12 y $18{ }^{\circ} \mathrm{C}$. Temperatura del mes más frío entre -3 y 18 grados. Las zonas más elevadas del Iztaccíhuatl están cubiertas de nieve y a su alrededor presenta praderas de alta montaña; las faldas inferiores de la Sierra Nevada están dedicadas en su mayoría a la agricultura de temporal. Al oriente presenta zonas de agricultura de riego, que forma parte de la gran zona de regadío que circunda San Martín Texmelucan y la más grande del Valle de Puebla.

El municipio de Tlapanalá se localiza en la parte suroeste del Estado de Puebla. Sus coordenadas geográficas son los paralelos $18^{\circ} 38^{\prime} 24^{\prime \prime}$ y $18^{\circ} 44^{\prime} 06^{\prime \prime}$ $\mathrm{N}$ y los meridianos $98^{\circ} 28^{\prime} 18^{\prime \prime}$ y $98^{\circ} 35^{\prime} 36^{\prime \prime} \mathrm{O}$. El municipio tiene topografía plana en general con un suave descenso en dirección noreste-suroeste, que va de 1500 a $1300 \mathrm{~m}$ de altitud. El municipio se localiza dentro de la zona de climas cálidos del Valle de Izúcar de Matamoros, identificándose dos: semicálido y cálido subhúmedo. La mayor parte del municipio presenta áreas dedicadas a las actividades agrícolas; existen grandes zonas de agricultura de temporal. Las áreas montañosas están cubiertas por selva baja caducifolia asociada a vegetación secundaria arbórea y arbustiva. welfare, their distribution, and their relation with the sociodemographic and productive characteristics of rural households.

\section{Methodology}

\section{Location of the study area}

The municipality of San Salvador el Verde is located in the central-west part of the state of Puebla. Its geographic coordinates are parallels $19^{\circ} 12^{\prime} 18^{\prime \prime}$ and $19^{\circ} 21^{\prime} 54^{\prime \prime} \mathrm{N}$ and meridians $98^{\circ} 26^{\prime} 54^{\prime \prime}$ and $98^{\circ} 93^{\prime} 18^{\prime \prime} \mathrm{W}$. The transition from temperate climates in Valle de Puebla to semi-cold in the low parts of Sierra Nevada is present in the municipality. The mean annual temperature is $12-18{ }^{\circ} \mathrm{C}$. The temperature of the coldest month is between -3 and 18 degrees. The highest zones of the Iztaccíhuatl are covered in snow and there are high-mountain meadows around them; the lower slopes of the Sierra Nevada are devoted mostly to rainfed agriculture. To the east, there are zones of irrigation agriculture that are part of the large irrigation zone that surrounds San Martín Texmelucan and the largest from Valle de Puebla.

The municipality of Tlapanalá is located in the southwestern part of the state of Puebla. Its geographical coordinates are parallels $18^{\circ} 38^{\prime} 24^{\prime \prime}$ and $18^{\circ} 44^{\prime} 06^{\prime \prime} \mathrm{N}$ and meridians $98^{\circ} 28^{\prime} 18^{\prime \prime}$ and $98^{\circ}$ $35^{\prime} 36^{\prime \prime} \mathrm{W}$. The municipality has a flat topography in general with a soft descent in the northeast-southwest direction, which ranges from 1500 to $1300 \mathrm{~m}$ of altitude. The municipality is located within the zone of warm climates in Valle de Izúcar de Matamoros, with two identified: semi-warm and sub-humid warm. The greater part of the municipality presents areas devoted to agricultural activities; there are large rainfed agricultural zones. The mountainous areas are covered with low deciduous forest associated to secondary tree and shrub vegetation.

The municipality of Coatzingo is located in the central-southern part of the state of Puebla. Its coordinates are parallels $18^{\circ} 31^{\prime} 36^{\prime \prime}$ and $18^{\circ} 39^{\prime}$ $36^{\prime \prime} \mathrm{N}$ and meridians $98^{\circ} 08^{\prime} 18^{\prime \prime}$ and $98^{\circ} 14^{\prime} 60^{\prime \prime}$ W. It presents a single climate of warm type: subhumid with summer rains. A large part of its territory is covered with low deciduous forest; its location coincides with that of Litosol and Regosol soils, and both with the zones that present a certain slope in 
El municipio de Coatzingo, se localiza en la parte centro sur del estado de Puebla. Sus coordenadas geográficas son los paralelos $18^{\circ} 31^{\prime} 36^{\prime \prime}$ y $18^{\circ} 39^{\prime}$ $36^{\prime \prime} \mathrm{N}$ y los meridianos $98^{\circ} 08^{\prime} 18^{\prime \prime}$ y $98^{\circ} 14^{\prime} 60^{\prime \prime}$ O. Presenta un solo clima de tipo cálido: subhúmedo con lluvias en verano. Una gran parte de su territorio está cubierta con selva baja caducifolia; su ubicación coincide con la de los suelos litosol y regosol, y ambos con las zonas que presentan cierto declive en su relieve. Existe un área importante dedicada a la agricultura de riego en la zona plana; intermedio entre las zonas de riego y las áreas de selva baja caducifolia se cuenta con zonas de agricultura de temporal que cubren un área considerable.

Se construyó una muestra por conglomerados en dos etapas. Se seleccionó este método debido a que no existe un marco de muestreo de hogares, pero sí se conocían las comunidades dentro de cada uno de los municipios seleccionados. Las unidades primarias estuvieron formadas por municipios, y las unidades secundarias por los hogares, dentro de cada municipio. Este es un diseño de muestreo probabilístico, cuya principal característica es que la población se divide en agrupaciones naturales; en este caso, municipios y comunidades a las que denominamos conglomerados.

En la primera etapa se seleccionaron tres municipios con probabilidades proporcionales a su tamaño; en la segunda se realizó un muestreo aleatorio simple. Para la selección aleatoria de los hogares se dividió cada núcleo poblacional en cuadrantes y en cada uno de ellos se distribuyó el número predeterminado de hogares. La encuesta piloto y su aplicación final se realizaron en septiembre y noviembre de 2014 con la participación de cuatro profesionistas con formación socioeconómica previamente capacitadas. En esta etapa se realizaron tres acciones simultáneamente; se capacitó a los encuestadores, se levantó la encuesta piloto, se corrigió el cuestionario estructurado, y se aplicó el cuestionario estructurado, cara a cara, a los jefes(as) de familia. Para conocer a mayor detalle aspectos de hábitos de consumo y gasto a través del año se realizarán dos entrevistas en profundidad en cada municipio, a informantes clave; jefes(as) de hogar de mucha confianza, con los que los investigadores han mantenido relaciones de trabajo por varios años.

Los municipios seleccionados para el estudio son San Salvador el Verde, Tlapanalá y Coatzingo, y el principal criterio de selección fue el contraste detectado en recorridos de campo, en sus características their relief. There is an important area devoted to irrigation agriculture in the flat zone; intermediate between the irrigation zones; and in the areas of low deciduous forest there are rainfed agriculture zones that cover a considerable area.

A sample was built by conglomerates in two stages. This method was selected because there is no framework for household sampling, although the communities within each one of the municipalities selected were known. The primary units were formed by municipalities, and the secondary units by households, inside each municipality. This is a probabilistic sampling design, whose principal characteristic is that the population is divided into natural groups; in this case, municipalities and communities that we call conglomerates.

In the first stage, three municipalities with probabilities proportional to their size were selected; in the second, a simple random sampling was carried out. For the random selection of households, each population units was divided into quadrants and in each one the predetermined number of households was distributed. The pilot survey and its final application were carried out in September and November 2014, with the participation of four professionals with socioeconomic training who were previously trained. In this stage, three actions were carried out simultaneously; the surveyors were trained, the pilot survey was applied, the structured questionnaire was corrected, and the structured questionnaire was applied, face to face, to heads of family. To understand in greater detail aspects of consumption habits and expenditure throughout the year, two in-depth interviews were performed in each municipality, with key informants; reliable heads of household, with whom the researchers have kept working relations for several years.

The municipalities selected for the study are San Salvador el Verde, Tlapanalá and Coatzingo, and the main selection criterion was the contrast detected in field visits, in their productive and sociodemographic characteristics. Table 3 presents the household sample and their distribution.

\section{Questionnaire design and data analysis method}

The questionnaire was made up of 10 sections: sociodemographic and housing characteristics; agricultural and livestock productive activities; 
Cuadro 3. Población, muestra y distribución de los hogares seleccionados. Table 3. Population, sample and distribution of the households selected.

\begin{tabular}{|c|c|c|c|c|c|}
\hline Municipios & Localidades & $\begin{array}{l}\text { Núm. de } \\
\text { Hogares }\end{array}$ & Población total & Muestra & Porcentaje \\
\hline \multirow{6}{*}{ San Salvador el Verde } & San S. el Verde & 632 & 2768 & 19 & 13.5 \\
\hline & Analco & 538 & 2515 & 15 & 10.6 \\
\hline & Hueyacatitla & 966 & 4526 & 16 & 11.3 \\
\hline & Aztotoacan & 551 & 2547 & 16 & 11.3 \\
\hline & Atzitzintla & 743 & 3398 & 11 & 7.8 \\
\hline & Tlacotepec & 518 & 2403 & 19 & 13.5 \\
\hline \multirow{3}{*}{ Tlapanalá } & Tlapanalá & 649 & 2718 & 12 & 8.5 \\
\hline & Coatepec & 291 & 1393 & 12 & 8.5 \\
\hline & Tepapayeca & 318 & 1329 & 13 & 9.2 \\
\hline Coatzingo & Coatzingo & 784 & 2964 & 8 & 5.7 \\
\hline Total & & 5990 & 26561 & 141 & 100.0 \\
\hline
\end{tabular}

Fuente: elaboración propia. Source: authors' elaboration.

productivas y sociodemográficas. El Cuadro 3 presenta la muestra de hogares y su distribución.

\section{Diseño del cuestionario y métodos de análisis de datos}

El cuestionario se integró por 10 secciones; características sociodemográficas y vivienda; actividades productivas agropecuarias; comercio y servicios; transferencias, migración, financiamiento; recursos naturales e imprevistos; activos productivos; consumo del hogar; organización, comercialización y otros servicios, y seguridad alimentaria. Las escalas de medición fueron de tipo nominal, ordinal y de razón, con un total de 157 preguntas.

\section{Medición del ingreso y la desigualdad}

El bienestar social se calculó con base en los conceptos de pobreza absoluta y relativa (Foster, 1998). Para el primero se utilizó el enfoque de líneas de pobreza, definidas como un ingreso inferior al ingreso umbral requerido para satisfacer las necesidades básicas. La otra medida del bienestar es la medición de la pobreza relativa, o la desigualdad, que se define como la forma en que se distribuye la riqueza en una sociedad, es decir, cuánto recibe una persona en comparación con otros miembros de la sociedad. La desigualdad puede medirse para cualquier distribución en una población, pero cuando se habla de la desigualdad económica se refiere a la distribución del consumo o el ingreso en la población (Foster, 1998). En este estudio estimamos la desigualdad en el ingreso y en el consumo. commerce and services; transferences, migration, financing; natural and unforeseen resources; household consumption; organization, commercialization and other services; and food security. The measuring scales were nominal, ordinal and rational, with a total of 157 questions.

\section{Measuring the income and the inequality}

Social welfare was calculated based on the concepts of absolute and relative poverty (Foster, 1998). For the first, the poverty lines approach was used, defined as income lower than the threshold income required to satisfy basic needs. The other welfare measure is the measurement of relative poverty, or inequality, which is defined as the way in which wealth is distributed in a society, that is, how much a person receives in comparison to other members of society. Inequality can be measured for any distribution in a population, but when speaking of economic inequality, it refers to the distribution of consumption or income in the population (Foster, 1998). In this study we estimate inequality in income and in consumption.

There are many methods for measuring inequality in income and consumption, each one with its characteristics and limitations. The most frequently used measure is the Gini index. The coefficient varies between zero and one. A Gini coefficient of zero reflects full equality, while a Gini coefficient of 1 shows perfect inequality (Medina, 2001). Graphically, the Gini index can be represented as the area between the Lorenz curve of the income distribution and a hypothetical equality line. The 
Hay varios métodos para medir la desigualdad del ingreso o del consumo, cada uno con sus características y limitaciones. La medida más utilizada es el índice de Gini. El coeficiente varía entre cero y uno. Un coeficiente de Gini de cero refleja la igualdad completa, mientras que un coeficiente de Gini de 1 muestra la desigualdad perfecta (Medina, 2001). Gráficamente, el índice de Gini puede representarse como el área entre la curva de Lorenz de la distribución del ingreso y una línea hipotética de igualdad. La curva de Lorenz traza la participación en el ingreso acumulado contra la distribución de la población. En caso de igualdad perfecta, la curva de Lorenz sería la misma que la línea de igualdad, lo que hace que el índice de Gini sea cero. El coeficiente de Gini es capaz de proporcionar una base para el juicio de valor de la desigualdad de ingresos. El estándar aceptado internacionalmente es que si el valor del coeficiente de Gini es menor que 0.2, la distribución de ingresos observado es altamente similar; si el valor varía entre 0.2 y 0.3 , la distribución de ingresos es relativamente media; si está entre 0.3 y 0.4 , la distribución del ingreso es moderadamente alta; y si es superior a 0.4 , la desigualdad del ingreso tiende a ser grande (You Hongbing, 1998).

La segunda medida de la desigualdad es el índice entrópico de Theil (Theil, 1967), que deriva de la noción de entropía de la teoría de la información; es una medida de concentración más fina que el coeficiente de Gini. El índice de Theil se normaliza en un intervalo de entre cero y uno, donde valores cercanos a cero significan una menor desigualdad, y cercanos a uno mayor desigualdad. Este indicador otorga una mayor ponderación a las transferencias realizadas a individuos u hogares con bajos niveles de ingreso, por lo que indica que existe una mayor reducción de la desigualdad ante una transferencia hacia un estrato bajo que hacia uno medio, y cumple con el axioma de descomposición aditiva; es decir, una transferencia de una persona más rica a una más pobre hace disminuir el índice.

El coeficiente de Gini y el índice de Theil cumplen con las propiedades de los buenos indicadores que miden la concentración del ingreso, lo que justifica su uso en este trabajo. Principalmente satisfacen dos condiciones que son deseables en la estimación de la desigualdad; independencia de escala, es decir, que no debe existir variación ante cambios proporcionales por los valores de la variable o cambios de
Lorenz curve traces the participation in the income accumulated versus the population distribution. In the case of perfect equality, the Lorenz curve would be the same as the equality line, which makes the Gini index zero. The Gini coefficient is capable of providing a basis for the value judgement of income inequality. The internationally accepted standard is that if the Gini coefficient is lower than 0.2, the income distribution observed is highly similar; if the value varies between 0.2 and 0.3 , the income distribution is relatively average; if it is between 0.3 and 0.4 , the income distribution is moderately high; and if it is higher than 0.4 , the income inequality tends to be large (You Hongbing, 1998).

The second measure of inequality is the entropic Theil index (Theil, 1967), which derives from the notion of entropy of the information theory; it is a finer concentration measurement than the Gini coefficient. The Theil index is normalized in an interval between zero and one, where values close to zero mean lower inequality, and close to one higher inequality. This indicator gives greater weighting to the transferences performed to individuals or households with low levels of income, indicating that there is a greater reduction of inequality in face of a transference towards a low stratum than towards a middle one, and fulfills the axiom of additive decomposition; that is, a transference from a richer person to a poorer one makes the index decrease.

The Gini coefficient and the Theil index fulfill the properties of good indicators that measure income concentration, which justifies their use in this study. Mainly, they satisfy two conditions that are desirable in the estimation of inequality; scale independence, that is, that there shouldn't be variation in face of proportional changes due to the values of the variable or changes in scale. The Pigou-Dalton condition or weak transference principle means that the inequality must be reduced if there is transference of income from a rich household to a poor one. There is a third condition that only the Theil index fulfills, and it is called strong transference principle or condition of relative change. This criterion demands that the concentration measure has a greater decrease in inequality if the income redistribution is made from a rich household to a poor one, than if the transference is made from a rich household to one of middle income (Medina, 2001). 
escala. Condición Pigou-Dalton o principio débil de transferencia, lo que significa que la desigualdad debe reducirse si existe una transferencia de ingresos de un hogar rico a uno pobre. Existe una tercera condición que solo cumple el índice de Theil y se denomina principio fuerte de transferencia o condición de cambio relativo. Este criterio exige que la medida de concentración tenga una mayor disminución en la desigualdad si la redistribución del ingreso se hace de un hogar rico a uno pobre, que si la transferencia se hiciera de un hogar rico a uno de ingresos medios (Medina, 2001).

Para el análisis de los datos, además del cálculo del índice de Gini y Theil, siguiendo la metodología propuesta por Haughton y Khandker (2009), se utilizó análisis de varianza para comparar la media de algunas variables relacionadas con la pobreza y la desigualdad, entre municipios, y el análisis de regresión múltiple para explicar el comportamiento del ingreso de los hogares.

\section{Resultados y Discusión}

Las características sociodemográficas y económicas de los municipios seleccionados muestran diferencias importantes. A nivel general, $32 \%$ de los hogares tienen jefa de hogar y al interior de los municipios es similar, excepto para Coatzingo, con $16 \%$. La edad promedio de los jefes(as) de hogar es de 48 ańos, menor que lo reportado por INEGI (2015) para el estado de Puebla.

Un factor que potencialmente afecta en forma negativa los esfuerzos de los hogares para colocarse en actividades no agropecuarias es el nivel de escolaridad de los productores (Reardon et al., 2001), pues se tiene que en Puebla, $86.4 \%$ de los jefes y jefas de las UP tienen grado de primaria o menos (INEGI, 2007). La escolaridad promedio encontrada para los municipios en estudio es de 7.8 ańos. Llama la atención que el promedio de escolaridad de los jefes(as) de hogar de Coatzingo es de casi 10 ańos.

La lengua indígena prácticamente no está presente en la muestra. El porcentaje de hogares que reciben programas sociales y que cuentan con seguridad social es relativamente bajo, tanto a nivel general como al interior de los municipios. Sobresale San Salvador el Verde, que tiene 43.8 de hogares que reciben programas sociales. Puebla es una de las entidades con menor acceso a créditos en el país, únicamente superado
For the data analysis, in addition to the calculation of the Gini and Theil indexes, following the methodology proposed by Haughton and Khandker (2009), analysis of variance was used to compare the mean of some variables related to poverty and inequality, between municipalities, and the multiple regression analysis was used to explain the behavior of income of households.

\section{Results AND Discussion}

The sociodemographic and economic characteristics of the municipalities selected show important differences. At the general level, $32 \%$ of the households have a woman head of household and inside the municipalities it is similar, except for Coatzingo, with $16 \%$. The average age of heads of households is 48 years old, younger than what was reported by INEGI (2015) for the state of Puebla.

A factor that potentially affects negatively the efforts of households to be placed in non-agricultural activities is the level of schooling of the producers (Reardon et al., 2001), since it is found that in Puebla, $86.4 \%$ of the men and women heads of households of the PUs have studied primary school or less (INEGI, 2007). The average schooling found for the municipalities in study is 7.8 years. It is noteworthy that the schooling average of the men and women heads of households in Coatzingo is almost 10 years.

The indigenous language is practically not present in the sample. The percentage of households that receive social programs and that have social security is relatively low, both at the general level and inside the municipalities. San Salvador el Verde stands out, which has $43.8 \%$ of households that receive social programs. Puebla is one of the states with least access to credits in the country, only exceeded by Veracruz and Chiapas. The proportion of households from the sample that received credit in the last five years is relatively low; it was 19.0, 8.0 and $25.0 \%$ for San Salvador el Verde, Tlapanalá, and Coatzingo, respectively. According to the Agricultural and Livestock Census 2007, 3 \% of the PUs in Puebla stated having access to bank credits, while the agricultural and livestock census from 2012 (INEGI, 2015) revealed that $7.68 \%$ of the PUs had access to formal or informal credit. In addition to the low access to financial services that predominates in the rural sector of Puebla, it should be highlighted that 
por Veracruz y Chiapas. La proporción de hogares de la muestra que recibieron crédito en los últimos cinco años es relativamente bajo; esta fue de 19.0, 8.0 y 25.0 \% para San Salvador el Verde, Tlapanalá, y Coatzingo, respectivamente. De acuerdo con el Censo Agropecuario 2007, 3 \% de las UP en Puebla manifestaron tener acceso a crédito bancario, en tanto que el conteo agropecuario del 2012 (INEGI, 2015) reveló que $7.68 \%$ de las UP tuvo acceso a crédito formal o informal. Adicionalmente, al pobre acceso a los servicios financieros que predomina en el sector rural de Puebla es de resaltar la baja penetración que ha tenido la banca de desarrollo en la Entidad. Sobresale que de las UP que manifestaron recibir crédito, la banca comercial atendió a $16.5 \%$; Financiera Rural, a $8.1 \%$ de estas; las Uniones de Crédito, al $6.3 \%$; SOFOLES, a $1.3 \%$ : y el resto recibe el crédito de diversas fuentes. El porcentaje de hogares que realizan ahorro es muy similar al de aquellos con crédito. El ahorro está estrechamente ligado al crédito en estos municipios.

Las remesas no son un tipo de ingreso importante en los hogares de los municipios seleccionados; el porcentaje de estos con este tipo de ingreso no rebasó $16.2 \%$, lo que habla de poca migración. El promedio de dinero que recibieron los hogares por este concepto fue de 3000 pesos por ańo. Los que tienen parcelas donde practican la agricultura y la ganadería constituyen $70 \%$, con servicio de riego en más de $50 \%$ de las parcelas, lo que está relacionado con una actividad agropecuaria importante, especialmente en Coatzingo. Los eventos inesperados, como granizadas, heladas y exceso de lluvia, principalmente, se presentan con mucha frecuencia, ocasionando una reducción de entre 10 a $20 \%$ en los rendimientos unitarios de cultivos como maíz, frijol, hortalizas y frutales (Cuadro 4).

La estructura de la producción en el estado de Puebla es un factor importante a tomar en cuenta para valorar las posibilidades de generación de ingreso y niveles de bienestar de los hogares rurales. En Puebla, $70.4 \%$ de las UP realizan actividades agropecuarias o forestales. El tamaño promedio de las UP que realizan este tipo de actividades es de 3.16 hectáreas.

La agricultura es una de las principales actividades en la entidad, seguida de la ganadería, y las actividades no agropecuarias. El tamaño de los predios adquiere relevancia si se considera que, en el caso de the development bank has had low penetration in the state. It stands out that out of the PUs which manifested receiving credit, commercial banks serviced $16.5 \%$; Financiera Rural, $8.1 \%$; Credit Unions, $6.3 \%$; SOFOLES, $1.3 \%$; and the rest received credit from diverse sources. The percentage of households that save is quite similar to those with credit. Savings are closely linked to credit in these municipalities.

Remittances are not an important type of income in the households of the municipalities selected; the percentage of these with this type of income did not exceed $16.2 \%$, which signals scarce migration. The average of money that the households received from this concept was 3000 pesos per year. Those that have plots where they practice agriculture and livestock production constituted $70 \%$, with irrigation service in more than $50 \%$ of the plots, which is related to an important agricultural/livestock activity, especially in Coatzingo. Unexpected events, such as hailstorms, frosts and excess rain, mainly, are present quite frequently, causing a reduction of between 10 and $20 \%$ in the unitary yields of crops like maize, bean, vegetables and fruit trees (Table 4).

The population structure in the state of Puebla is an important factor to take into account to assess the possibilities of income generation and levels of welfare of the rural households. In Puebla, $70.4 \%$ of the PUs carries out agricultural, livestock or forestry activities. The average size of the PU that performs this type of activities is 3.16 hectares.

Agriculture is one of the main activities in the state, followed by livestock production, and nonagricultural activities. The size of the plots becomes relevant when considering that, in the case of agriculture, for it to be competitive and profitable it is necessary to have a minimum scale depending on the type of crop and access to irrigation, which in the municipalities studied is present in an important manner. The average surface in the study zone is 2.1 hectares sown. In general, Coatzingo presents better productive and sociodemographic conditions than the other two municipalities; for example, it has double the surface sown than San Salvador el Verde and Tlapanalá, higher index of assets, number of livestock heads, and housing index (Table 5).

The sociodemographic and productive characteristics of Coatzingo are reflected in its social characteristics. The per capita income is more than 
Cuadro 4. Descripción de la muestra; general y tres municipios.

Table 4. Description of the sample; general and three municipalities.

\begin{tabular}{|c|c|c|c|c|c|}
\hline \multicolumn{2}{|c|}{ Variable/categoría } & $\begin{array}{c}\text { S. Salvador el Verde } \\
(\%)\end{array}$ & $\begin{array}{c}\text { Tlapanalá } \\
\text { (\%) }\end{array}$ & $\begin{array}{c}\text { Coatzingo } \\
(\%)\end{array}$ & $\begin{array}{l}\text { General } \\
(\%)\end{array}$ \\
\hline \multirow{2}{*}{ Género } & Hombre & 67.7 & 64.9 & 84.0 & 68.1 \\
\hline & Mujer & 32.3 & 35.1 & 16.0 & 31.9 \\
\hline \multirow{2}{*}{ Lengua indígena } & Sí & 4.2 & 0.0 & 0.0 & 2.8 \\
\hline & No & 95.8 & 100.0 & 100.0 & 97.2 \\
\hline \multirow{2}{*}{ Programas sociales } & Sí & 43.8 & 16.2 & 12.5 & 34.8 \\
\hline & No & 56.3 & 83.8 & 87.5 & 65.2 \\
\hline \multirow{2}{*}{ Seguridad social } & Sí & 17.7 & 0.0 & 0.0 & 12.1 \\
\hline & No & 82.3 & 100.0 & 100.0 & 87.9 \\
\hline \multirow{2}{*}{ Servicio de crédito } & Sí & 18.8 & 8.1 & 25.0 & 16.3 \\
\hline & No & 81.3 & 91.9 & 75.0 & 83.7 \\
\hline \multirow{2}{*}{ Servicio de ahorro } & Sí & 18.8 & 8.1 & 12.5 & 13.5 \\
\hline & No & 81.3 & 91.9 & 87.5 & 86.5 \\
\hline \multirow{2}{*}{ Recibe remesas } & Sí & 6.3 & 16.2 & 4.0 & 8.5 \\
\hline & No & 93.8 & 83.8 & 96.0 & 91.5 \\
\hline \multirow{2}{*}{ Tiene parcelas } & Sí & 66.3 & 73.0 & 87.5 & 69.8 \\
\hline & No & 33.7 & 27.0 & 12.5 & 30.2 \\
\hline \multirow{2}{*}{ Régimen humedad } & Riego & 77.8 & 71.4 & 50.0 & 74.1 \\
\hline & Temporal & 22.2 & 28.6 & 50.0 & 25.9 \\
\hline \multirow{2}{*}{ Eventos inesperado } & Sí & 43.8 & 10.8 & 50.0 & 35.5 \\
\hline & No & 56.3 & 89.2 & 50.0 & 64.5 \\
\hline
\end{tabular}

Fuente: elaboración propia con datos de encuesta 2014. Source: authors' elaboration with data from the 2014 survey.

la agricultura, para que ésta sea competitiva y rentable es necesario contar con una escala mínima dependiendo del tipo de cultivo y el acceso al riego, que en los municipios estudiados, está presente de forma importante. La superficie promedio en la zona de estudio es de 2.1 hectáreas sembradas. En general Coatzingo presenta mejores condiciones productivas y sociodemográficas que los otros dos municipios; por ejemplo, tienen el doble de superficie sembrada que San Salvador el Verde y Tlapanalá, mayor índice de activos, número de cabezas de ganado e índice de la vivienda (Cuadro 5).

Las características sociodemográficas y productivas de Coatzingo se reflejan en las características sociales. El ingreso per cápita es más del doble que los otros dos municipios, el consumo de calorías es mayor en $25 \%$, y el gasto en alimentos es $75 \%$ mayor que en San Salvador el Verde y que en Tlapanalá. El gasto no alimentario es muy similar en los tres municipios. Es de notar que la inseguridad alimentaria en Coatzingo es cuatro veces menor que en los otros municipios, y la pobreza también son menores. Existen algunas características que podrían explicar estas diferencias (Cuadro 6).

La población en situación de pobreza en los tres municipios estudiados es superior a la reportada en double than in the other two municipalities, the calorie consumption is higher in $25 \%$, and the expenditure in foods is $75 \%$ higher than in San Salvador el Verde and Tlapanalá. The non-dietary expenditure is quite similar in the three municipalities. It is noteworthy that food insecurity in Coatzingo is four times lower than in the other municipalities, and poverty is also lower. There are some characteristics that could explain these differences (Table 6).

The population in poverty in the three municipalities studied is higher than the one reported in official statistics; $73 \%$ according to our calculations, and $64.5 \%$ according to CONEVAL (2015).

The ANOVA test results show that there are significant differences $(\alpha \leq 0.05)$ in sociodemographic, productive variables, and welfare indicators, primarily between Coatzingo and the two other municipalities. In the means of the variables: schooling of the head of household, surface of land sown, number of livestock heads, and asset index, there are significant differences. It is not the case of the housing index and the dependence rate, which belong to the same group. There is also difference in per capita income, agricultural and livestock income, and calorie consumption per person, in which the means in 
Cuadro 5. Estadísticos descriptivos de los municipios en estudio.

Table 5. Descriptive statistics of the municipalities of study.

\begin{tabular}{|c|c|c|c|c|}
\hline Variable & $\begin{array}{l}\text { S. Salvador } \\
\text { el Verde }\end{array}$ & Tlapanalá & Coatzingo & General \\
\hline Edad (años) & 48.9 & 47.7 & 41.4 & 48.1 \\
\hline Escolaridad (años) & 7.5 & 6.4 & 9.8 & 7.3 \\
\hline Superficie sembrada (ha) & 2.5 & 2.4 & 5.4 & 2.1 \\
\hline Número de cabezas & 0.9 & 1.6 & 1.6 & 0.7 \\
\hline Índice de activos $(0-1)$ & 0.32 & 0.31 & 0.51 & 0.33 \\
\hline Tasa de dependientes (\%) & 31.5 & 31.5 & 38.1 & 31.9 \\
\hline Índice de vivienda (0-1) & 0.78 & 0.83 & 0.84 & 0.81 \\
\hline Calorías per cápita & 2047.8 & 1971.9 & 2615.7 & 2060.1 \\
\hline Ingreso agropecuario $(\$)$ & 590.1 & 1060.2 & 1301.5 & 753.8 \\
\hline Ingreso no agropecuario $(\$)$ & 748.3 & 471.2 & 1143.6 & 698.0 \\
\hline Ingreso total $(\$)$ & 1358.1 & 1547.5 & 2470.1 & 1470.9 \\
\hline Gasto total alimento $(\$)$ & 488.0 & 437.6 & 766.6 & 490.6 \\
\hline Gasto total no alimento \$) & 691.3 & 635.5 & 661.0 & 675.0 \\
\hline Gasto total $(\$)$ & 1179.4 & 1073.1 & 1427.6 & 1165.6 \\
\hline Inseguridad alimentaria (\%) & 54.2 & 48.6 & 12.5 & 50.4 \\
\hline Sin bienestar (Pobreza) (\%) & 77.1 & 75.7 & 25.1 & 73.2 \\
\hline
\end{tabular}

Fuente: elaboración propia con datos de encuesta 2014. Source: authors' elaboration with data from the 2014 survey.

Nota: el índice de activos y el de vivienda están en una escala de cero a uno. Note: the index of assets and housing is in a scale of zero to one.

las estadísticas oficiales; $73 \%$ según nuestros cálculos y de $64.5 \%$ según CONEVAL (2015).

Los resultados de la prueba ANOVA muestran que hay diferencias significativas $(\alpha \leq 0.05)$ en variables sociodemográficas, productivas e indicadores de bienestar, principalmente entre Coatzingo y los
Coatzingo are higher and statistically different (Table 7). The average energy ( $\mathrm{kcal}$ ) requirements are 2200 (CONEVAL, 2015). It is observed that San Salvador el Verde and Tlapanalá have an average consumption under the national average; instead, the consumption in Ocotzingo is higher in approximately $25 \%$.

Cuadro 6. Diferencia de medias (ANOVA) de variables seleccionadas.

Table 6. Means difference (ANOVA) of selected variables.

\begin{tabular}{|c|c|c|c|c|c|c|c|}
\hline \multirow{2}{*}{ Actividades } & \multicolumn{2}{|c|}{$\begin{array}{l}\text { S. Salvador } \\
\text { el Verde }\end{array}$} & \multicolumn{2}{|c|}{ Tlapanalá } & \multicolumn{2}{|c|}{ Coatzingo } & \multirow[t]{2}{*}{$\begin{array}{c}\text { Estadístico } \\
\mathrm{F} / \mathrm{p} \text {-valor }\end{array}$} \\
\hline & $\bar{X}$ & Dif. & $\bar{X}$ & Dif. & $\bar{X}$ & Dif. & \\
\hline Escolaridad (años) & 7.47 & $\mathrm{a}$ & 6.40 & $\mathrm{a}$ & 9.75 & $\mathrm{~b}$ & $5.86(.004)$ \\
\hline Superficie (ha) & 2.49 & a & 2.36 & a & 5.37 & $\mathrm{~b}$ & $0.61(.541)$ \\
\hline Número de cabezas & 0.53 & $\mathrm{a}$ & 1.06 & $\mathrm{~b}$ & 1.08 & $\mathrm{~b}$ & $0.51(.601)$ \\
\hline Índice de activos & 0.27 & $\mathrm{a}$ & 0.26 & a & 0.53 & $\mathrm{~b}$ & $7.19(.001)$ \\
\hline Tasa de dependientes & 31.51 & a & 31.52 & a & 38.09 & a & $0.27(.762)$ \\
\hline Índice de vivienda & 0.78 & a & 0.81 & a & 0.83 & a & $1.39(.251)$ \\
\hline Ingreso anual/ persona $(\$)$ & 16587 & a & 14806 & a & 40484 & $\mathrm{~b}$ & $7.79(.001)$ \\
\hline Ingreso agropecuario $(\$)$ & 28352 & $\mathrm{a}$ & 45618 & $\mathrm{~b}$ & 47718 & $\mathrm{~b}$ & $2.67(.072)$ \\
\hline Ingreso no agropecuario $(\$)$ & 38642 & a & 21562 & $\mathrm{a}$ & 49577 & a & $1.63(.198)$ \\
\hline Gasto alimentos $(\$)$ & 488 & $\mathrm{a}$ & 437 & $\mathrm{~b}$ & 766 & c & $6.42(.002)$ \\
\hline Gasto no alimentos $(\$)$ & 691 & $\mathrm{a}$ & 635 & $\mathrm{a}$ & 660 & a & $0.027(.973)$ \\
\hline Calorías diarias & 1848 & $\mathrm{a}$ & 2006 & $\mathrm{a}$ & 2633 & $\mathrm{~b}$ & $3.69(.026)$ \\
\hline
\end{tabular}

Fuente: elaboración propia con datos de encuesta 2014. Source: authors' elaboration with data from the 2014 survey. Nota: el índice de activos y de vivienda están en una escala de cero a uno. * Note: the index of assets and housing is in a scale of zero to one. 
otros dos municipios. En las medias de las variables: escolaridad del jefe, superficie sembrada de tierra, número de cabezas de ganado e índice de activos, existe diferencia significativa. No es el caso del índice de vivienda y la tasa de dependencia, que pertenecen al mismo grupo. También existe diferencia en el ingreso per cápita, en el ingreso agropecuario, y en el consumo de calorías por persona, en las cuales las medias de Coatzingo son mayores y estadísticamente diferentes (Cuadro 7). Los requerimientos de energía (kcal) promedio estimado son de 2200 (CONEVAL, 2015). Se observa que San Salvador el Verde y Tlapanalá tienen un consumo promedio por debajo del promedio nacional; en cambio el consumo es Ocotzingo es superior en aproximadamente $25 \%$.

\section{La desigualdad}

La distribución del ingreso y del consumo en los municipios estudiados presenta diferencias importantes. El índice de Gini y Theil estimó una desigualdad mayor para San Salvador el Verde y menor para Tlapanalá y Coatzingo. Es importante notar que en este orden, San Salvador el Verde, Tlapanalá, y Coatzingo presentan un índice de mayor a menor en pobreza e inseguridad alimentaria (CONEVAL, 2015).

En el caso de México es importante mencionar que, en general, los estados y municipios con mayores niveles de pobreza por ingresos son también aquellos con mayores niveles de desigualdad. Los elevados niveles de desigualdad en nuestro país tienen implicaciones importantes en su desarrollo, pues limitan el

\section{Inequality}

The distribution of the income and consumption in the municipalities studied presents important differences. The Gini and Theil indexes estimated a higher inequality for San Salvador el Verde and a lower one for Tlapanalá and Coatzingo. It is important to note that in this order, San Salvador el Verde, Tlapanalá and Coatzingo present a higher to lower index in poverty and food insecurity (CONEVAL, 2015).

In the case of México it is important to mention that, in general, the states and municipalities with higher levels of income poverty are also those with highest levels of inequality. The high levels of inequality in our country have important implications in its development, for they limit the impact of economic growth in the reduction of poverty (De Ferranti et al., 2004).

This situation is accompanied by important restrictions for poverty reduction, since high levels of inequality prevent a better redistribution of the resources generated by the economy and, therefore, it is necessary to implement specific public policies that lead to the modification of the distribution of resources in these states and municipalities.

\section{Explanatory factors of the income}

The household income is one of the most frequently used ways of understanding the ability to obtain goods and services, such as foods, health,

Cuadro 7. Distribución del ingreso y del gasto en los municipios estudiados, 2014.

Table 7. Distribution of income and expenditure in the municipalities studied, 2014.

\begin{tabular}{|c|c|c|c|c|c|c|}
\hline \multirow{2}{*}{ Conceptos } & \multicolumn{2}{|c|}{ S. Salvador el Verde } & \multicolumn{2}{|c|}{ Tlapanalá } & \multicolumn{2}{|c|}{ Coatzingo } \\
\hline & Gini & Theil & Gini & Theil & Gini & Theil \\
\hline Ingreso Monetario* $(\$)$ & 0.430 & - & 0.380 & - & 0.430 & - \\
\hline Ingreso per cápita (\$) & 0.502 & 0.440 & 0.439 & 0.445 & 0.416 & 0.371 \\
\hline Ingreso agropecuario $(\$)$ & 0.618 & 0.447 & 0.528 & 0.408 & 0.541 & 0.281 \\
\hline Ingreso no agropecuario $(\$)$ & 0.659 & 0.449 & 0.776 & 0.571 & 0.741 & 0.536 \\
\hline Gasto total $(\$)$ & 0.428 & 0.415 & 0.296 & 0.251 & 0.193 & 0.128 \\
\hline Gasto alimentario (\$) & 0.261 & 0.144 & 0.273 & 0.228 & 0.181 & 0.112 \\
\hline Gasto no alimentario $(\$)$ & 0.605 & 0.668 & 0.415 & 0.228 & 0.251 & 0.186 \\
\hline
\end{tabular}

*Estimado oficial del CONEVAL (2015). Official estimate by CONEVAL (2015).

Fuente: elaboración propia con datos de encuesta 2014. Source: authors' elaboration with data from the 2014 survey. 
impacto del crecimiento económico en la reducción de la pobreza (De Ferranti et al., 2004).

Esta situación se acompaña de importantes restricciones para la reducción de la pobreza, ya que altos niveles de desigualdad impiden una mejor redistribución de los recursos generados por la economía y, por tanto, es necesario emprender políticas públicas específicas que conduzcan a la modificación de la distribución de recursos en estas entidades y municipios.

\section{Factores explicativos del ingreso}

El ingreso de los hogares es una de las formas más utilizadas para conocer la capacidad de obtener satisfactores, tales como alimentos, salud, recreación, y educación, entre otros. Los resultados de la ecuación de ingreso, en este estudio, revelan la importancia tanto de variables de capital humano como de tipo productivo. La contribución a la explicación de los ingresos en los hogares de la muestra, en orden de importancia, es: los activos productivos, la escolaridad del jefe(a) del hogar, el número de cabezas de ganado y la ocupación del jefe (Cuadro 8).

En la misma dirección de los resultados arriba mencionados, los activos productivos de los hogares (tierra, medios de transporte, maquinaria y equipo) tienen un efecto positivo y significativo en el ingreso de los hogares (Yúnez y Meléndez, 2007). recreation and education, among others. The results from the income equation, in this study, reveal the importance of variables both of human capital and productive type. The contribution to the explanation of household incomes from the sample, in order of importance, is: productive assets, schooling of the man or woman head of household, number of livestock heads, and the head of household's occupation (Table 8).

In the same direction of the results mentioned before, the productive assets of the households (land, transportation means, machinery and equipment) have a positive and significant effect on the household income (Yúnez and Meléndez, 2007). Concerning education, Reardon et al. (2001) reported that this is a variable that is related with the selection of nonagricultural and non-livestock activities, and also with higher levels of income in the rural households.

An intervention that tends to improve the situation of poverty and inequality in the municipalities studied should consider increasing the educational level and the endowment of productive assets of the households, as well as the role of the non-agricultural and non-livestock activities. These non-agricultural and non-livestock activities play an important role in improving the income of rural households. Regarding this point, De Janvry and Sadoulet (2001) find that the participation of the non-agricultural and non-

Cuadro 8. Resultados de la ecuación de ingreso para la muestra y municipios.

Table 8. Results from the income equation for the sample and municipalities.

\begin{tabular}{|c|c|c|c|c|}
\hline Municipios & Coeficiente & Sig. & Estadístico F & $R^{2}$ y $R^{2}$ ajustada \\
\hline \multicolumn{5}{|l|}{ San Salvador el Verde } \\
\hline Edad (años) & 158.4 & $(.028)$ & \multirow{5}{*}{$(41.236)$} & \multirow{5}{*}{$(.809)(.783)$} \\
\hline Escolaridad (años) & 2288.1 & $(.000)$ & & \\
\hline Trabajo no agropecuario $(\$)$ & 4938.5 & $(.027)$ & & \\
\hline Activos productivos $(\$)$ & 31995.0 & $(.000)$ & & \\
\hline Número de cabezas & 6584.6 & $(.000)$ & & \\
\hline \multicolumn{5}{|l|}{ Tlapanalá } \\
\hline Edad (años) & 120.2 & $(.052)$ & \multirow{4}{*}{$(18.953)$} & \multirow{4}{*}{$(.795)(.763)$} \\
\hline Escolaridad (años) & 1517.5 & $(.040)$ & & \\
\hline Activos productivos $(\$)$ & 29034.8 & $(.005)$ & & \\
\hline Número de cabezas & 974.6 & $(.001)$ & & \\
\hline \multicolumn{5}{|l|}{ General } \\
\hline Escolaridad (años) & 2451.1 & $(.000)$ & \multirow{4}{*}{$(38.331)$} & \multirow{4}{*}{$(.728)(.703)$} \\
\hline Activos productivos $(\$)$ & 26724.9 & $(.000)$ & & \\
\hline Número de cabezas & 2017.8 & $(.000)$ & & \\
\hline Ocupación del Jefe & -594.4 & $(.053)$ & & \\
\hline
\end{tabular}

Fuente: elaboración propia con datos de encuesta 2014. Source: authors' elaboration with data from the 2014 survey. 
Con respecto a la educación, Reardon et al. (2001) reportaron que esta es una variable que está relacionada con la selección de actividades no agropecuarias y también con mayores niveles de ingreso de los hogares rurales.

Una intervención tendiente a mejorar la situación de pobreza y desigualdad en los municipios estudiados deberá considerar aumentar el nivel educativo y la dotación de activos productivos de los hogares, así como el papel de las actividades no agropecuarias. Estas actividades no agropecuarias juegan un papel importante en mejorar el ingreso de los hogares rurales. Sobre este punto, De Janvry y Sadoulet (2001) encuentran que la participación del ingreso no agropecuario en el total de los hogares rurales de México es de más de $50 \%$ y que está asociado con mayores niveles educativos.

Para tener confianza sobre los resultados del modelo de regresión, además de observar valores del estadístico $\mathrm{F}$ y $\mathrm{R}^{2}$ satisfactorios, probamos los supuestos del modelo; distribución normal de los errores del modelo, autocorrelación entre residuales (DW), y colinealidad (una variable explicativa no es combinación lineal de otra variables independiente). Para la normalidad de los errores se realizó la prueba de Shapiro-Wilk. El p-valor calculado fue 0.52, lo que indica que no podemos rechazar que los errores están normalmente distribuidos. La auto-correlación se probó con el estadístico Durbin-Watson, que tuvo un valor de 1.969 , por lo que rechazamos autocorrelación entre las variables independientes. Finalmente, el estadístico Factor de Inflación de la Varianza (FIV) promedio para el grupo de variables explicativas fue de 1.199, por lo que rechazamos que alguna de las variables explicativas sea una combinación lineal.

\section{Conclusiones}

La importancia del estudio del bienestar social de los hogares rurales, estimado con base en el ingreso y el consumo de los hogares a nivel municipal radica en que los resultados pueden usarse para el diseño de estrategias de intervención específicas, atendiendo características socio-demográficas y productivas. Los indicadores de bienestar y desigualdad de los municipios seleccionados muestran diferencias significativas. La pobreza e inseguridad alimentaria es mayor en San Salvador el Verde y Tlapanalá que en Coatzingo. El índice de Gini estimó una desigualdad livestock income in the total of rural households in México is more than $50 \%$ and that it is associated to higher educational levels.

To have confidence in the results from the regression model, in addition to observing satisfactory values of the $F$ and $R^{2}$ statistics, we tested the model's assumption; normal distribution of the model's errors, autocorrelation between residuals (DW), and collinearity (an explanatory variable is not a linear combination of other independent variables). For the normality of the errors, the Shapiro-Wilk test was performed. The $p$-value calculated was 0.52 , which indicates that we cannot reject that the errors are distributed normally. The autocorrelation was tested with the Durbin-Watson statistics, which had a value of 1.969, which is why we reject autocorrelation between the independent variables. Finally, the average Variance Inflation Factor (VIF) statistics for the group of explanatory variables was 1.199, which is why we reject that some of the explanatory variables are a linear combination.

\section{ConClusions}

The importance of the study of social welfare of rural households, estimated based on the income and the consumption of households at the municipal level, lies in that the results can be used for the design of specific intervention strategies, addressing sociodemographic and productive characteristics. The indicators of welfare and inequality in the municipalities selected show significant differences. Poverty and food insecurity is higher in San Salvador el Verde and Tlapanalá than in Coatzingo. The Gini index estimated a higher inequality for San Salvador el Verde and lower for Tlapanalá and Coatzingo. It is important to note that in that order, San Salvador el Verde, Tlapanalá and Coatzingo present a higher to lower index in poverty and food insecurity. A possible explanation of this is the endowment of productive assets; among them, surface sown, irrigation and use of productive technology, in addition to a higher educational degree of the head of household, in favor of Coatzingo. A public policy that tends to improve the situation of poverty and inequality in the municipalities studied should consider increasing the educational level and the endowment of productive assets of the poorest households, as well as the promotion of non-agricultural and non-livestock 
mayor para San Salvador el Verde y menor para Tlapanalá y Coatzingo. Es importante notar que en este orden, San Salvador el Verde, Tlapanalá, y Coatzingo presentan un índice de mayor a menor en pobreza e inseguridad alimentaria. Una posible explicación de lo anterior es la dotación de activos productivos, entre ellos, superficie sembrada, riego y uso de tecnología productiva, además de un mayor grado educativo del jefe del hogar, a favor de Coatzingo. Una política pública tendiente a mejorar la situación de pobreza y desigualdad en los municipios estudiados deberá considerar aumentar el nivel educativo y la dotación de activos productivos de los hogares más pobres, así como la promoción de empleo no agropecuario. Específicamente deberá aumentarse el grado de escolaridad de los integrantes del hogar en edad escolar, posiblemente con apoyo económico para que no abandonen la primaria y secundaria. Los adultos deberán capacitarse en la actividad que más les genera ingresos, sea agropecuaria o no agropecuaria. Los activos productivos que deben aumentar son maquinaria y equipo que permita agregar valor a la producción agrícola. Finalmente, para los hogares con dotación baja de tierra agrícola, incentivar actividades no agropecuarias, principalmente pequeños comercios y oficios.

\section{Literatura Citada}

Arrow, Kenneth Joseph. 1974. Elección social y valores individuales. Ministerio de Economía y Hacienda. ISBN 978-847196-111-2.

Cejudo, Córdoba Rafael. 2007. Capacidades y libertad. Una aproximación a la teoría de Amartya Sen. Revista Internacional de Sociología, Vol 65, No. 47. doi:10.3989/ris.2007. i47.50.

CONAPO (Consejo Nacional de Población). 2005. La desigualdad en la distribución del ingreso monetario en México Primera edición: diciembre de 2005. ISBN: 970-628-851-1.

CONEVAL (Consejo Nacional de Evaluación de la política de Desarrollo Social). 2014. Medición de la pobreza en México 2014. Disponible en: http://www.coneval.gob.mx. Consultado en octubre 2015.

CONEVAL (Consejo Nacional de Evaluación de la política de Desarrollo Social). 2015. La pobreza por ingresos en México. Disponible en: http://www.coneval.gob.mx/rw/resource/ coneval/info_public/PDF_PUBLICACIONES/POBREZA_INGRESOS_MEXICO_WEB.pdf. Consultado en octubre 2015.

De Ferranti, David, Guillermo Perry E., Francisco H. Ferrerira G., and Michael Walton. 2004. Inequality in Latin América: Breaking with history? The World Bank, Washington, D.C. P. 380.

De Janvry, Alain, y Elisabeth Sadoulet. 2001. Income strategies among rural households in Mexico: The role of off-farm activities. World development, 29(3), 467-480. employment. Specifically, the degree of schooling of the household members of school age should be increased, possibly with economic support so that they do not abandon primary and secondary school. Adults should be trained in the activity that generates most income, whether agricultural and livestock production, or not. The productive assets that should increase are machinery and equipment that allow adding value to agricultural production. Finally, for the households with low endowment of agricultural land, encouraging non-agricultural and non-livestock activities, primarily small-scale commerce and trades.

$$
\text { - End of the English version - }
$$

Debreu, Gerard. 1959. Theory of Value: An axiomatic analysis of economic equilibrium. New Haven: Yale University Press.

Di Pasquale, Eugenio. 2008. La operacionalización del concepto de Bienestar Social: un análisis comparado de distintas mediciones. Observatorio Laboral Revista Venezolana, 1(2), 17-42. ISSN 1856-9099.

Foster, E. James. 1998. Absolute versus Relative Poverty. The American Economic Review, Vol. 88, No. 2. pp: 335-341.

Haughton, Jonathan, and Khandker R. Shahidur. 2009. Handbook on poverty and inequality. The World bank. http:// www.sideso.df.gob.mx/documentos/desigualdad_monetaria_conapo.pdf Consultado en enero 2016. 419 p.

INEGI (Instituto Nacional de Estadística y Geografía). 2007. Censo Agrícola, Ganadero y Forestal. Disponible en: http:// www.inegi.org.mx/est/contenidos/proyectos/Agro/ca2007/ Resultados_Agricola/. Consultado en octubre 2015.

INEGI (Instituto Nacional de Estadística y Geografía). 2010. Censo agropecuario. Disponible en: http://www.inegi.org. mx. Consultado en octubre 2015.

INEGI (Instituto Nacional de Estadística y Geografía). 2015. Censo agropecuario. Disponible en: http://www.inegi.org. mx. Consultado en octubre 2015.

Litchfield, A. Julie. 1999. Inequality: Methods and Tools. World Bank's Web Site on Inequality, Poverty, and Socio-economic Performance: Disponible en: http://www.worldbank.org/poverty/inequal/index.html . Consultado Nov. 2015.

Medina, Fernando. 2001. Consideraciones sobre el índice de Gini para medir la concentración del ingreso. CEPAL-SERIE Estudios estadísticos y prospectivos. Santiago de Chile, marzo de 2001, Serie 9.

Rawls, John. 1971. A Theory of Justice. Harvard University Press. ISBN: 0-674-01772-2. Estados Unidos de América.

Reardon, Thomas, Julio Berdegué, and German Escobar. 2001. Rural Nonfarm Employment and Incomes in Latin America: Overview and Policy Implications en World Development. Vol. 29, núm. 1, pp: 395-409.

Rodríguez, Z. M., F. L. Becerra, y H. I. Alonso. 2008. Bienestar social y desigualdad del ingreso: diferentes enfoques para su medición. Revista OIDLES. Vol. 2, No 5 (diciembre 2008). Disponible en: http://www.eumed.net/rev/oidles/05/index.htm 
Sen, Amartya Kumar. 1970. Collective Choice and Social Welfare. San Francisco: Holden-Day.

Sen, Amartya Kumar. 1992. Inequality Reexamined. Oxford University Press Inc., New York. Pp. 207.

Sen, Amartya Kumar. 1999. Reason Before Identity. Oxford University Press, USA; $1^{\text {st }}$ edition.

SIAP (Servicio de Información Agroalimentaria y Pesquera). 2015. Producción Agropecuaria y Pesquera. Disponible en: http://www.siap.gob.mx/agricultura-produccion-mensual Consultado en octubre 2015.
Theil, Henri. 1967. Economics and information theory. Amsterdam: North-Holland. P. 488.

You, Hongbing. 1998. A Study of the Income Inequality in China. China Economics Press.

Yúnez Naude, A., y Á. Meléndez Martínez. 2007. Efectos de los activos familiares en la selección de actividades y en el ingreso de los hogares rurales de México. Investigación Económica, vol. LXVI, núm. 260, abril-junio, 2007. pp: 49-80. 